\title{
Public open space initiatives for healthier cities in Rwanda
}

\author{
Ilija Gubic, Oana Baloi \\ Global Green Growth Institute, Rwanda \\ ilija.gubic@gggi.org | oana.baloi@gggi.org
}

\begin{abstract}
With a population of close to 13 million, and an annual growth rate of 2.86 percent, Rwanda plans to position itself as a climate resilient, low carbon, low unemployment, reduced poverty country, with a strong services sector by 2050 . Its projected increase in its urbanization rate from a current value of 18.4 percent to 35 percent by 2024 is driven by strong political will, significant investments in infrastructure, service provision, and human capital development. Rwanda's secondary cities, identified as economic nodes of growth, are currently undergoing revision of their masterplans in consideration of climate change realities and the pressure on infrastructure and services due to rapid urbanization. Currently, cities in Rwanda do not yet have a system of public open spaces. Where available, such spaces are usually hardly accessible and need upgrading. To address this, the Ministry of Infrastructure, Rwanda Housing Authority, City of Kigali and six secondary cities have committed to deliver on public open space related activities and targets under the yearly performance contract 'Imihigo'. The outcomes of their commitments support the climate-responsive revision of masterplans of the City of Kigali and six secondary cities. This paper presents public open space initiatives in Kigali and the results of the technical assessment of public open spaces and participatory planning and design workshop in Nyagatare, secondary city in Rwanda's. It also discusses ongoing policy changes and initiatives that aim to promote public open spaces as crucial for urban public health.
\end{abstract}

Keywords: public open space, resilience, masterplan, secondary city, Kigali, Nyagatare, Rwanda

To cite this article:

Gubic, I., Baloi, O. (2020). Public open space initiatives for healthier cities in Rwanda. The Journal of Public Space, 5(2), I29-I46, DOI I0.3289I/jps.v5i2. 1287

This article has been double blind peer reviewed and accepted for publication in The Journal of Public Space. This work is licensed under a Creative Commons Attribution - Non Commercial 4.0 International License https://creativecommons.org/licenses/by-nc/4.0/ 


\section{Introduction}

Rwanda has one of the highest annual urban growth rates - an estimated 4.5 percent in East Africa. Estimates indicate the country's urbanization rate will increase from around I8.4 percent currently to 35 percent by 2024 (Ministry of Infrastructure, 2019). Rwanda's Economic Development and Poverty Reduction Strategy (20I3-20 I8) identified six secondary cities as potential poles of urban growth to reduce migration to the capital city and develop opportunities in Rwanda's mostly border cities: Huye, Muhanga, Musanze, Nyagatare, Rubavu and Rusizi. These secondary cities' populations account for a quarter of the country's urban population (Ministry of Infrastructure and Global Green Growth Institute, 2016) and contribute 13 percent to its GDP (World Bank, 2017). Rural-urban migration is driven by limited land surface and rural poverty. Despite policies favouring green cities and buildings in Rwanda, rapid urbanization is driving further greenhouse gas (GHG) emission sources such as transportation, construction and industries. In areas along main roads, vehicle emissions are the largest contributor to poor air quality, while domestic stoves are the largest contributor in rural areas (Rwanda Environment Management Authority, 2018). Air pollution in urban and rural settings is comprised of a mix of chemicals, particulate matter and biological materials that may contribute to breathing problems, chronic diseases and premature mortality (International Association for Medical Assistance to Travelers, 2020). In previous years, more than two thousand deaths per year have been attributed to ambient air pollution, a major risk factor in Rwanda for respiratory diseases (Rwanda Environment Management Authority, 2018).

Against this backdrop of rapid urban growth and increased GHG emissions, public open spaces are a key element in ensuring social cohesion (Peters, Elands, \& Buijs, 2010) and wellbeing with wide-ranging benefits to public health (Cicea \& Pirlogea, 20I I; Hoffimann, Barros, \& Ribeiro, 2017) and the environment (Rakhshandehroo, Tahir, Yusof, \& Yunos, 2017). Research on public open spaces in rapidly urbanizing Rwanda's cities is limited. That could be explained by the general interest of research institutions and development partners in issues related mainly to the provision of basic urban services such as electricity, water supply, waste management, while public open spaces are still regarded more as a commodity (Gubic \& Baloi, 2019).

To contribute to the prevention of air pollution and to the overall health of its urban residents, the Ministry of Infrastructure, Rwanda Housing Authority, the Global Green Growth Institute and other stakeholders including local governments, are leading public open spaces planning, design and implementation in the City of Kigali and six secondary cities. This article addresses some of the findings of the initiative that are in line with national policies and also with recommendations from Sustainable Development Goals (SDGs) and the New Urban Agenda (NUA).

\section{Development Agenda's Recommendations: Health Benefits of Public Open Spaces}

Health-based urban planning promotes opportunities for increased physical activity and social capital, reduced crime, obesity reduction, diabetes reduction, reduced hypertension, depression and improved access to healthy food (Grant, 20I5; Mogo, Lerno, Abdeta, \& Olufemi, 2019). Political support is needed to ensure adequate allocation of resources for better integration of health, environmental, social and 
economic concerns in land-use planning, transport, housing and economic development policies (Barton, Grant, Mitcham, Tsourou, 2009). In addition to accessible health facilities, urban planning must reduce environmental risks and provide more public open spaces that can create conditions for healthy, active lifestyles (London Healthy Urban Development Unit, 20I4). The adoption by the UN Member States of Agenda 2030 in September 2015 was a major milestone: for the first time there was clear recognition from the international community of the need to focus on sustainable urbanization, with SDG I I, "make cities and human settlements inclusive, safe, resilient and sustainable", dedicated to this aim. This included a specific provision on public spaces (SDG II.7): "By 2030, provide universal access to safe, inclusive and accessible, green and public spaces, in particular for women and children, older persons and persons with disabilities" (UN General Assembly, 20 I7). SDG I I also pledges to achieve sustainable development through "making cities inclusive, safe, resilient and sustainable" by reducing the number of deaths and the number of people affected by disasters, including waterrelated disasters; reducing the environmental impact of cities by paying special attention to air quality, and provision of universal access to safe, inclusive and accessible, green and public spaces (UN General Assembly, 20I7).

In 2016, countries across the world adopted the New Urban Agenda (NUA) during the UN Conference on Housing and Sustainable Urban Development (Habitat III) in Quito, Ecuador. The NUA was the culmination of three years of preparation involving a wide range of governments, observers, and stakeholders, with public spaces identified as one of the main priority areas (Habitat III Secretariat, 2016). The Issue Paper on public spaces, prepared during the Habitat III preparatory process, suggests that interaction with nature, through green public space, has been associated with general and mental health. It also suggests that urban ecosystem services like air pollution reduction and urban cooling have multiple long-term health benefits (Habitat III Secretariat, 20I7). During the preparatory process, Barcelona's local authority hosted a thematic meeting on public spaces: this resulted in the Barcelona Declaration, calling on governments to include public spaces in the NUA (UN General Assembly, 2016). The Barcelona Declaration also highlights the social and political dimension of public open spaces. It especially mentions recreation and health, insisting that public spaces should provide equal opportunities for enjoying indoor/outdoor spaces and promote healthy practices and sustainable consumption and production patterns in harmony with nature (UN General Assembly, 2016).

There was a great deal of collaboration between local authorities, civil society groups and other stakeholders in shaping inputs on public spaces for the NUA. These initiatives helped shape the final text of the NUA, with its emphasis on promoting safe, inclusive, accessible, green and quality public spaces (Gubic \& Baloi, 2019). The NUA (United Nations, 2016) mentions public spaces in paragraphs 36, 97, 99, and 109 through the lens of urban sustainability and as standalone commitments in paragraphs 13, 37, 53, 67, and 100. After the adoption of the NUA in October 2016, the Government of Rwanda undertook a review of its existing laws and policies against the NUA as part of the Rwanda State of the Environmental Outlook, prepared by the Rwanda Environment Management Authority (REMA) with support from the Ministry of Infrastructure and other stakeholders (Rwanda Environment Management Authority, 2017), though so far, no policies have actually been revised to localise the NUA (Gubic \& Baloi, 2019). 
Nevertheless, the Government of Rwanda has taken a positive step towards localizing and implementing the NUA through the organization by the Ministry of Infrastructure of the National Urban Forum (NUF), a multi-stakeholder platform to support sustainable urban development by creating awareness and promoting participation, coordination, engagement, and discussion in this area. For the NUF's "Implementing the New Urban Agenda", a number of stakeholders including the World Bank, the Global Green Growth Institute, the International Growth Centre (IGC), and UN-Habitat, led by the Ministry of Infrastructure, prepared a background paper on the Government of Rwanda's work to date on various urbanisation issues, including public open spaces, with projects in Rubavu public beach and Mount Rubavu highlighted as notable achievements in this area. The report also mentioned an assessment of public spaces in Nyagatare, Huye, and Rubavu (Ministry of Infrastructure, 2019) that will be presented as a case study in this article. Other initiatives, also held as parallel events to the NUF, included Urban Walk (Global Green Growth Institute, 2019a) and Inclusive Cities Talk (Global Green Growth Institute, 2019b), organized by the Global Green Growth Institute, all linked to the importance of public spaces and the inclusion of residents in their planning, design and implementation, as suggested in paragraph 97 of the NUA (United Nations, 2016). The two-day forum had facilitated intensive discussions on various topics around four main themes, with 17 recommendations emerging. One of the key recommendations is to protect and enhance wetlands and green public open spaces (Ministry of Infrastructure, 2020). Key actions were assigned to relevant institutions to implement the forum's recommendations.

\section{Research Question and Methods}

This article, drawing on research on public spaces in Rwanda's capital and Nyagatare, a secondary city' in Rwanda, examines whether current initiatives are embedded in a collaborative planning framework that meaningfully incorporates interaction among different stakeholders. Furthermore, it discusses health as a main benefit of green and public open spaces. It explores the following questions:

1) How does Rwanda's current approach to urban development reflect public health concerns, and does it align with global development agendas? This is answered by examining the process guiding the masterplan revisions for Kigali and Nyagatare.

2) To what extent do government decision-makers and Rwanda's development partners prioritize public open space initiatives for improved health? This is answered by examining the current government's initiatives addressing public open spaces and presenting outcomes of a thematic working group on public open

\footnotetext{
${ }^{\prime}$ Rwanda is approximately $18 \%$ urbanized, which is the lowest in Africa. However, the current average growth rate of the urban population is $4.5 \%$, which is well above the world average of $1.8 \%$. Moreover, this growth is largely concentrated in the capital city, Kigali, which has an annual population growth rate of $9 \%$. In order to better distribute economic growth across the country and accomplish the national urbanization target of $35 \%$ by 2020 , the Government of Rwanda has identified six secondary cities to serve as growth poles: Huye, Muhanga, Nyagatare, Rubavu, Musanze and Rusizi. However, these cities currently face challenges in the management and provision of basic infrastructure services to their growing population sizes, which, in turn, affect the ability of the cities to develop their economic prosperity (Republic of Rwanda, National Roadmap for Green Secondary City Development, 20I5. Available at: https://gggi.org/site/assets/uploads/2017/I2/National-Roadmap-for-Green-Secondary-CityDevelopment.pdf).
} 
Ilija Gubic, Oana Baloi

spaces chaired by the Ministry of Infrastructure and co-chaired by the Global

Green Growth Institute.

In the first section, a literature review and analysis of Rwanda's planning documents helps to explain the general context of urban development and the extent to which the existing national legislation addresses public spaces for health benefits of its citizens.

Secondly, data from field visits to Kigali, and the secondary city of Nyagatare present an in-depth understanding of the current trends in public open spaces in Rwanda. Thirdly, the authors draw on the results of quantitative surveys with 100 citizens of Kigali and Nyagatare, as well as more than 10 semi-structured qualitative interviews with government officials and professionals working in Rwanda.

\section{Public Space for Public Health in Rwanda's Planning Documents}

The main legislation regulating urbanization is the Law Governing Urban Planning and Building in Rwanda of 2012 (Rwanda, 20I2) and its implementing orders of 2015. Masterplans are guided by the National Land Use and Development Masterplan of 2010 which provides the general directives and principles for land use development including densification, mixed land use, mixed housing, green design, and participation. In Rwanda's National Land Use Planning Guidelines public spaces are all places publicly owned or of public use, accessible and enjoyable by all for free and without profit motive (Ministry of Natural Resources, 2017). Rwanda's Building Code does not define public space uses specifically but refers to 'recreational land use' (Ministry of Infrastructure, 20I5a). In that document, recreational land use includes public open space, greenways and green areas, recreation and sports facilities. It can be distinguished between spaces for passive recreation and spaces for active recreation (Ministry of Infrastructure, 2015a). The National Land Policy stated that green spaces, as well as valleys, would be protected, and suggests that the creation of parks and protection of existing green areas in urban zones could eventually be transformed into accessible open public spaces (Ministry of Lands, Environment, Forests, Water and Mines, 2004). The policy also presents a general framework for the future urban development of Rwanda, with reference to public space (Ministry of Infrastructure, 20I5b). The Rwanda National Land Use Planning Guidelines have also set guidelines for the promotion, protection, and creation of public, open, and green spaces in Rwanda (Ministry of Natural Resources, 2017). The Guidelines stipulate that open spaces, natural beauty, and environmentally sensitive areas should be maintained and developed for financial value (Ministry of Natural Resources, 2017). Financial value of public spaces is discussed in paragraph 53 of the NUA (United Nations, 2016) as a commitment to: promote safe, inclusive, accessible, green, and quality public spaces as drivers of social and economic development, in order to sustainably leverage their potential to generate increased social and economic value, including property value, and to facilitate business and public and private investments and livelihood opportunities for all. The document, in conformity with the Urban Planning Code (UPC), states that small neighbourhood parks should provide access to basic public space functions. For instance, it recommends that at least $5 \%$ of urban residential areas should be allocated to public spaces and facilities and provides recommended standards on the widths of sidewalks when designing intraurban roads (Ministry of Infrastructure, 2015c). In the upgrading and renewal of urban informal settlement, the guidelines stipulate that in conformity with Ministerial Order 
no. 04/Cab.M/0I 5 of I8/05/20I5 determining urban planning and building regulations and the Rwanda UPC, trees, green spaces should be preserved and restored. Furthermore, article 46 of the Organic Law no. 04/2005 of 08/04/2005 (Rwanda, 2005), determining the modalities of protection, conservation, and promotion of the environment in Rwanda, calls for the government and citizens to "establish, maintain, and manage parklands and green spaces".

Another planning document is the Green Growth and Climate Resilience National Strategy for Climate Change and Low Carbon Development (Government of Rwanda, 20II). Designed to support Rwanda's development into a climate-resilient, low-carbon economy by 2050 , the strategy suggests favouring the creation of high-density, walkable cities to avoid excessive sprawl and long commuting times. The strategy also recommends corridors for pedestrians and cyclists, and green public spaces to improve the population's quality of life (Government of Rwanda, 20 I I). Such wording aligns with paragraph 1 I 8 of the NUA (United Nations, 2016), calling for the provision of adequate pedestrian and cycling infrastructure. The national strategy also calls for urban areas that are attractive with trees, parks, and public spaces to promote low-carbon transport, improve quality of life, and reduce the risk of flooding (Government of Rwanda, 20I I). The experiences of other countries regarding flood prevention measures, where investments can be four times more cost-effective than post-disaster reconstruction (Lochhead, 2017; Silva \& Costa, 2018), highlight the importance of public spaces and resilient development in Rwanda, given the climate-induced challenges already evident in the country, particularly droughts and floods.

The Ministry of Infrastructure, with the Global Green Growth Institute, developed the National Roadmap for Green Secondary City Development (NRGSCD; Ministry of Infrastructure \& Global Green Growth Institute, 2016). Since the six cities are experiencing similar urban problems to those observed in Kigali, the Government of Rwanda deems that planning for the growth of those cities in a sustainable framework will increase benefits and avoid negative consequences such as urban sprawl, traffic congestion, the growth of informal settlements, and inadequate public services. To support green urban development in the six secondary cities, the authors of the NRGSCD recommend that they increase financial resources and local revenues to support investment in improved public spaces: these would, in turn, generate more public income.

In the absence of a clear definition of 'public spaces' in the Rwandan context, different terms with different meanings are used interchangeably in different governmental publications to mean 'public spaces'. To overcome the lack of clarity, the Ministry of Infrastructure, the Rwanda Housing Authority, Global Green Growth Institute, and the University of Rwanda are working on a review of existing laws and policies to support the development of a common and localised understanding of public space. In terms of policy frameworks, the government of Rwanda has launched the Green Growth and Climate Resilience: National Strategy for Climate Change and Low Carbon Development (October 20I I); Urban Planning and Building Code (May 2015), National Roadmap for Green Secondary Cities Development (December 2015), Green City Toolkit for Rwanda (November 2016) and National Land Use Development Masterplans. Through good governance, urban planning is aimed at job provision and ensuring quality of life for urban dwellers through the following pillars of urbanization: enhancing the building and construction sectors, energy, urban mobility and transport, 
water management and waste management. The above-mentioned planning documents underline District Development Plans and Strategies, strategic investment plans and annual investments plans developed and implemented by the sectorial ministries, districts and city authorities. Kigali and the six secondary cities mentioned above are undergoing the process of masterplan revision. As part of the green city development actions, the government has enabled critical progress through the ban on plastic bag use, development of National Land Use Development Masterplan and other connected masterplans with great consideration of Green Urbanization, adoption of 'Made in Rwanda' policy, promotion of Rwanda Cities 'Car Free Day' event, availability of 'Environmental protection unit' in the Rwanda National Police and the proposed ban of single use plastic bottles currently in process. Despite the government's active efforts for green and environmentally sound cities, there are challenges in increasing the number of private investors in waste management and recycling but also weaknesses due to the difficult topography that makes the adoption of non-motorized transport less feasible.

\section{I. District Development Strategies (DDS) Recognizing Public Spaces as Development Priorities}

District Development Strategies (DDS) 2018-2024 are a guide for Rwanda's 30 districts to achieve their development vision and objectives, Vision 2020 and Vision 2050, emphasising strategic interventions to implement the current NST I. DDSs were the result of a year-long consultation process reviewing what remained from the 20I3-2018 District Development Plan and developing new strategic interventions. While for 24 Rwandan districts the Ministry of Local Government (MINALOC) hired consultants to facilitate discussions and draft strategies, in Rwanda's six secondary cities, Global Green Growth Institute seconded its technical district assistants to facilitate discussions.

During the facilitation process with stakeholders, public spaces were identified as one of a number of important socio-economic public assets. To support the implementation of strategies, the Ministry of Infrastructure and the Rwanda Housing Authority have included public spaces as part of the yearly performance contract. The government-led mainstreaming of public spaces in the six secondary cities and districts is part of efforts to improve the response of cities to challenges induced by rapid urbanisation and implement the country's transformational strategy.

\subsection{Master Plan Revision}

The Global Green Growth Institute has worked in collaboration with the Government of Rwanda to develop the Green Climate Fund (GCF) Readiness Proposal for the Republic of Rwanda to access global funding for climate action. This readiness programme ended in December 2019 and strengthened the National Determined Authority's coordination capacity to align on-going climate finance efforts with green city and sustainable infrastructure development, through stakeholder engagement. The project provided a detailed physical plan of Nyagatare and other secondary cities, incorporating low emission and sustainable development strategies in line with national policies (Global Green Growth Institute, 2018c). Public space is one component of these much-needed resilience frameworks, contributing not only to climate change adaptation and disaster risk prevention but also yielding socio-economic, physical and other health benefits to urban residents. Given the geographical limitations, the 
masterplan revision is promising development of defined environmental protection zones such as protected forests, wetlands, heritage zones, and steep slopes will enable accessible green open spaces for leisure, sports and other health-promoting activities. It promotes projects such as an eco-resort area, community centres, wetland parks, forest parks and neighbourhood parks defined by the detailed zoning.

\subsection{Sector Working Group}

The government-led Sector Working Groups aim to improve the coordination of programme development and delivery across multiple government institutions and organisations (Gubic \& Baloi, 2019). The Sector Working Group on urbanisation and rural settlements is led by the urbanisation division of the Ministry of Infrastructure and World Bank. Members of the Sector Working Group are other line ministries, government agencies and stakeholders such as UN-Habitat, Global Green Growth Institute, RWN, and the University of Rwanda. One of four thematic sub-sector working groups is focusing on urbanization and public space, chaired by the Ministry of Infrastructure and co-chaired by the Global Green Growth Institute. The first meeting of the thematic sub-sector working group was held in October 2018 to ensure the programmes of actions were aligned to national priorities, as well as the identified priority areas for urban development (Ministry of Infrastructure, 2018). The second meeting was organized in July 2019 where stakeholders presented designs for planned and/or ongoing public open space related projects (Global Green Growth Institute, 2019c).

\section{Case Study: Kigali, initiatives for non-motorized transportation}

The updated masterplan for Kigali 2050, to be adopted in 2020, will provide corrective measures and updated direction to the urban growth of Kigali considering current trends including climate science and research. The rapid urban growth has resulted in unplanned development, increased numbers of motorized vehicles, and an increase in consumption of biomass for energy purposes. The development of Kigali as a sustainable city implies protecting sensitive ecological areas from unplanned urban growth, restoring damaged natural elements like water bodies, adopting natural resource management systems, green building initiatives, steep slope protection strategies, and the development of parks and green connectors.

Hills with prominent ridges define Kigali's topography. Unplanned developments can be found in the valleys around and within wetlands. The tops of the ridges have an average elevation of 1600 meters, while the valleys are around 1300 meters. Encroachment in wetlands is also a threat that affects both the ecosystem and human health as most of the encroachments are polluting industries. To this end, the masterplan revision recommends conserving wetlands and rehabilitating, as well as exploring nature areas for sustainable and strategic economic gains and green jobs. Rwanda Environment Management Authority and the Ministry of Environment (MoE) are conducting urban wetland mapping, restoration and design of urban wetlands as green public spaces to be used for recreation and leisure, contributing to the overall public health of city residents (Figure I).

Global Green Growth Institute (GGGI) supported the Rwanda Environment and Management Authority (REMA) to design a project proposal to strengthen climate 
resilience of the City of Kigali (I million EUR from the Government of Italy) specifically on urban wetland rehabilitation: The project focuses on restoring the degraded urban wetland in the city of Kigali called "Nyandungu". A I30ha urban wetland will conserve wetlands and habitat for wildlife and provide walking/cycling trails, fishponds, and botanical gardens for residents and tourists. The project seeks to increase biodiversity, reduce flood risk, raise awareness on wetland conservation, create green jobs and promote tourism. The project will not only increase the resilience of the city but also have long-term benefits for Kigali citizens because it is a public asset designed to address the need for recreational public space and provide jobs. This project is under implementation.

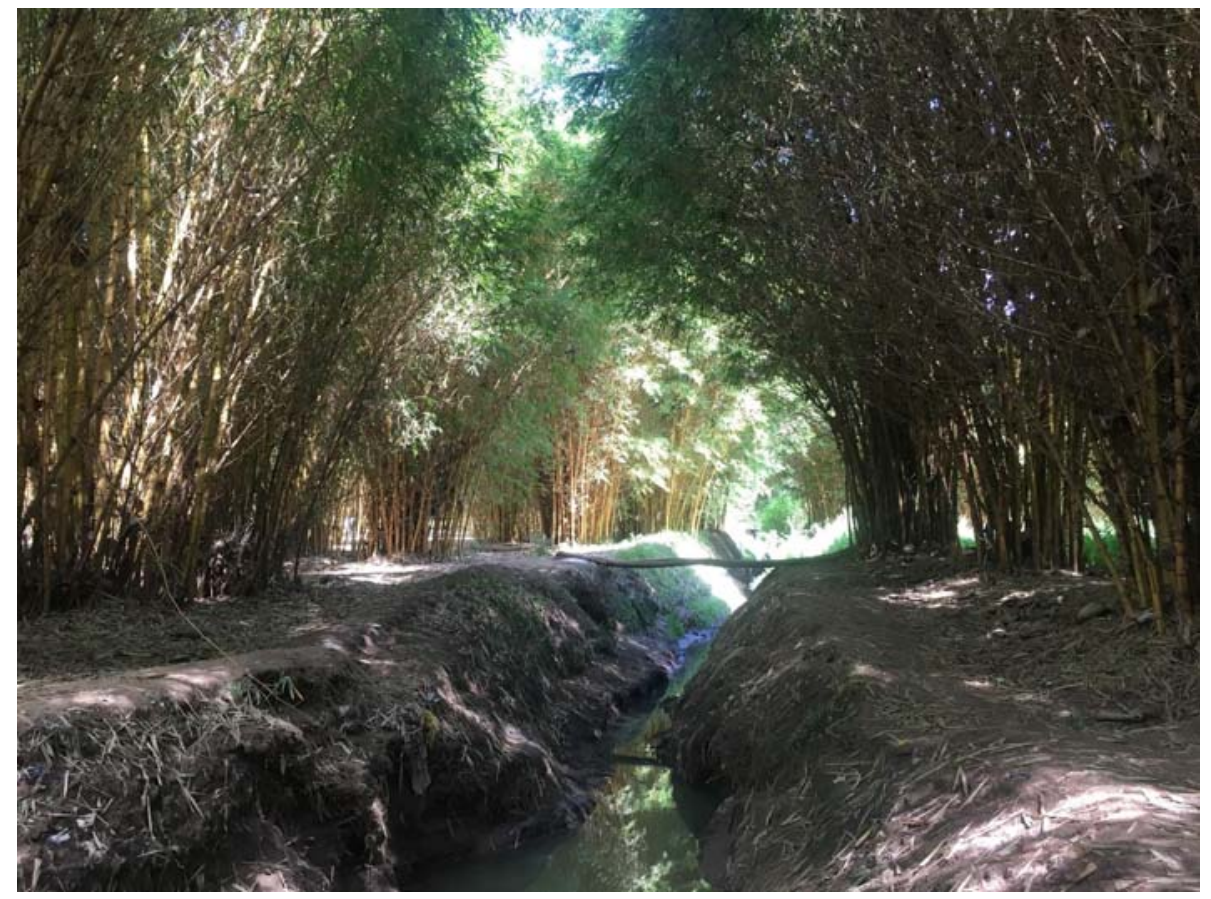

Figure I. Restored Urban Wetland in Kigali, Rwanda, further work is being done to transform the wetland into public open space for recreation and leisure, 2019 (Source: Oana Baloi)

In Kigali, urban development initiatives such as car free zones, expansion of roads for bus rapid transit, relocation of Industrial Parks, protection of wetlands and development of public open spaces are under implementation. The government is working on continued awareness and capacity development for urban resilience and potential projects for public and private investment. With public participation via expert discussions with communities during umuganda, for example, being a priority. Umuganda is a practice of community self-help and cooperation, reinforcing socioeconomic development.

Kigali is conducting monthly car-free days promoting physical activities such as fitness, jogging and outdoor games on urban roads temporary closed for vehicles (Figure 2). The car-free days reduce 24-hour GHG concentrations in the city, which are typically five times the limits stipulated by the WHO guidelines (Kalisa, et al., 20I7). The City of Kigali has designated a "car-free zone" in the city centre to reduce greenhouse gas 
emission levels and encourage greater use of public space. The City of Kigali is also promoting car-free zones in other neighbourhoods in a bi-monthly event, inviting urban dwellers to spend time outside for events such as sports activities, exhibitions, and performances.

Urban Walks, an initiative piloted by Global Green Growth Institute, is organized in Kigali and Rwanda's six secondary cities with the intention of highlighting pressing urban issues to residents (Global Green Growth Institute, 2018a). Access to public open space is important to increase recreational walking: while this is commonly referenced in high-income countries, there is little mention of this in middle-income and less developed countries (Florindo, et al., 2017), hence the value of engaging citizens through this form of activity.

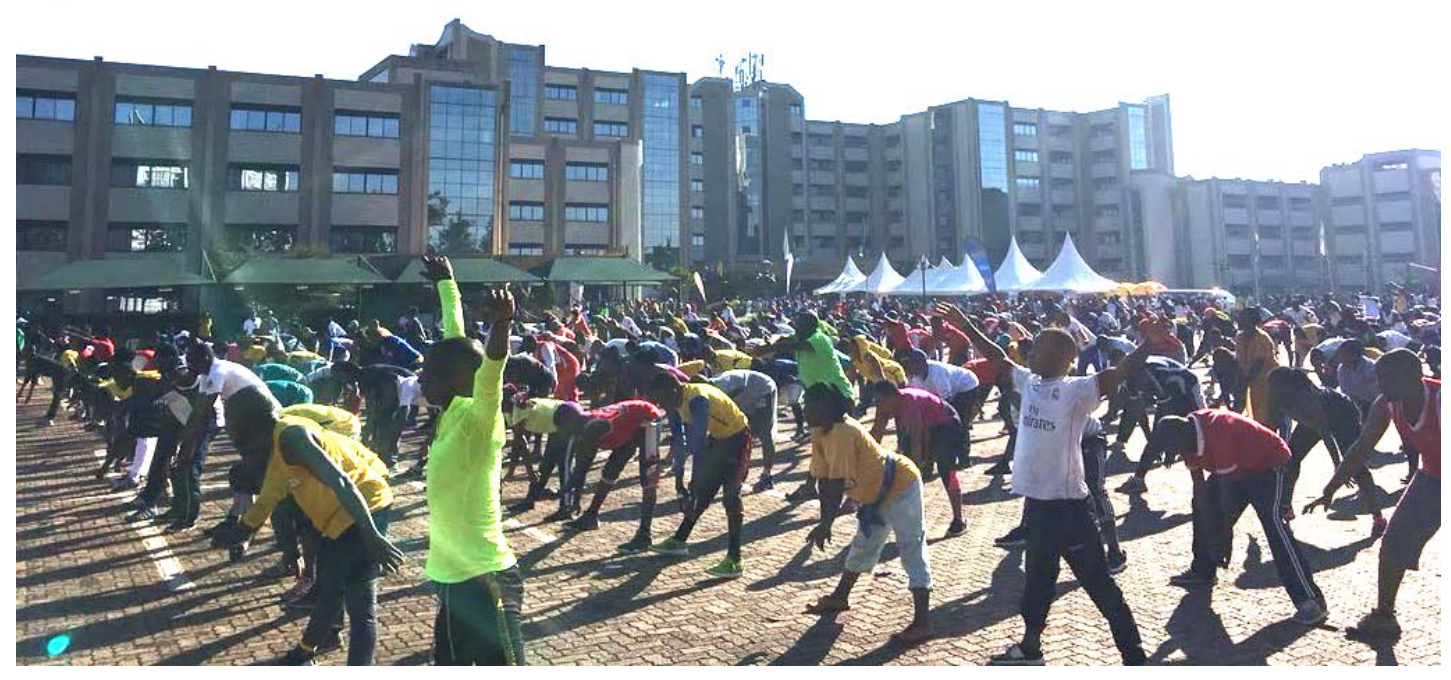

Figure 2. Rwandans at the Car Free Day in Kigali, a regular monthly initiative promoting recreation for public health, 2018 (Source: Ilija Gubic)

\section{Case Study: Nyagatare}

Nyagatare District is spread over an area of I,74I square kilometers making it the largest district of the country by area. Although Nyagatare has recorded high internal migration toward the Eastern Province absorbing significant investment in recent years (World Bank, 2016), the city has the lowest number of companies and job creation among the six secondary cities (World Bank, 2017).

In Nyagatare, the masterplan was developed in May 2015, and conceptually covered $10 \%$ of the planned developed area. The city of Nyagatare was a sparse human settlement in 1999, which has been expanding spatially at an average annual rate of 25 percent (World Bank, 2017). The unsustainable urban sprawl causes loss of high value agricultural land and natural habitat/biodiversity creating risks to urban food security (World Bank, 20I7), while the growth of urban unplanned settlements constrains the 
urban water supply, leading to limited sanitation and public health threats, diminishing urban livelihood opportunities, growing youth unemployment, inequality, social discontent and conflict. In Nyagatare, only 62 percent of households had access to clean water in 2017, achieved through the construction of a water treatment plant. There is a documented shortage of water and prolonged drought in five sectors of the district.

\section{I. Nyagatare Masterplan Revision}

The Nyagatare Masterplan revision process is aligned with the National Transformation Strategy and the District Development Strategy 2018-2024, as well as other government-led guiding documents such as National Roadmap for Green Secondary City Development (Global Green growth Institute, 2015) developed jointly by the Ministry of Infrastructure and Global Green Growth Institute.

The Global Green Growth Institute, the Ministry of Infrastructure, Rwanda Housing Authority, local authorities, and other stakeholders collaborated on the assessment of public spaces in Rwanda's secondary cities. The report titled "Mapping of Public Spaces to Inform Master Plan Review for Secondary Cities in Rwanda," (Rwanda Housing Authority \& Global Green Growth Institute, 2019) was developed after assessing 36 public spaces in six secondary cities in Rwanda, through citywide surveys that informed the revision of the masterplans.

Due to recent rapid urbanization in Rwanda, public spaces could play a vital role in determining the quality of life (Gubic \& Baloi, 20l9). Moreover, the assessment provides information on the necessary aspects for the design and implementation of public spaces, including street lighting, increased access for people living with disability (handrails, ramps, signs), and public toilets. The assessment also underlines the urgency of including public spaces in the green city and national planning agenda.

The revision of the Masterplan aims at the development of Nyagatare as a Green City. Nyagatare is facing climate impact that is worsened by water scarcity and prolonged droughts, deforestation, but also seasonal flooding. Water management, waste management construction and transport development are key in ensuring low emissions. The masterplan promotes green mobility encouraging compact growth, transit-oriented development, and a walkable city where public space design and implementation is imperative to allow socioeconomic and resilient neighbourhood development. Population projections for Nyagatare city by 2050 place it at approximately 450,000 (Nyagatare District Development Strategy, 2018). This will require double the amount of housing and facilities, calling for an approach of densification, contrary to the current sparse development trend. In order to prevent sprawl and plan for liveable neighbourhoods with mixed typology housing options, adequate amenities, and facilities, the masterplan is introducing flexible zoning regulations that allow for incremental development. Information shared by the District during the consultation meetings suggests that the detailed masterplan provides adequate urban green space aimed at 15 square kilometres capital urban green space by 2050, urban parks within walking distance $(400 \mathrm{~m})$ and promotes a participatory approach to planning (Global Green Growth Institute, 2019e). The masterplan also guides access to basic infrastructure to 100 percent of the population, including the promotion of recreation corridors along rivers and streams; the establishment of a hierarchy of open space systems, the rehabilitation of flood-prone areas and the development of drought hazard management. At the neighbourhood level, public space 
planning can improve urban quality, social cohesion and inclusion, and encourage activities fostering public health. Participatory planning, involving communities in managing urban commons contributes to improved spatial integration, human security and resilience, local democracy and social accountability (UN-Habitat, 20I5).

\subsection{Implementing the Masterplan of Nyagatare}

The Ministry of Infrastructure (MININFRA), the Rwanda Housing Authority (RHA), and the Global Green Growth Institute (GGGI) undertook a city-wide public space survey in Rwanda's secondary city of Nyagatare to understand the needs of citizens. Authors of this paper were representing Global Green Growth Institute in the process. The survey findings indicate that residents need safe, inclusive, and accessible green and public spaces and are willing to walk and ride bicycles to and from public spaces, and to maintain their cleanliness (Rwanda Housing Authority \& Global Green Growth Institute, 2019). The city of Nyagatare hosted a two-day public space participatory design workshop organized by MININFRA, RHA, and GGGI (Figure 3 and 4). Authors of this paper facilitated the workshop. Citizens from diverse backgrounds engaged in the design process, with each group listing the main elements to be incorporated in the public space to increase resilience, support the absorption of greenhouse gas emissions, and foster public health. This approach promotes greater gender equality and socioeconomic inclusion through safe, accessible public spaces for all.
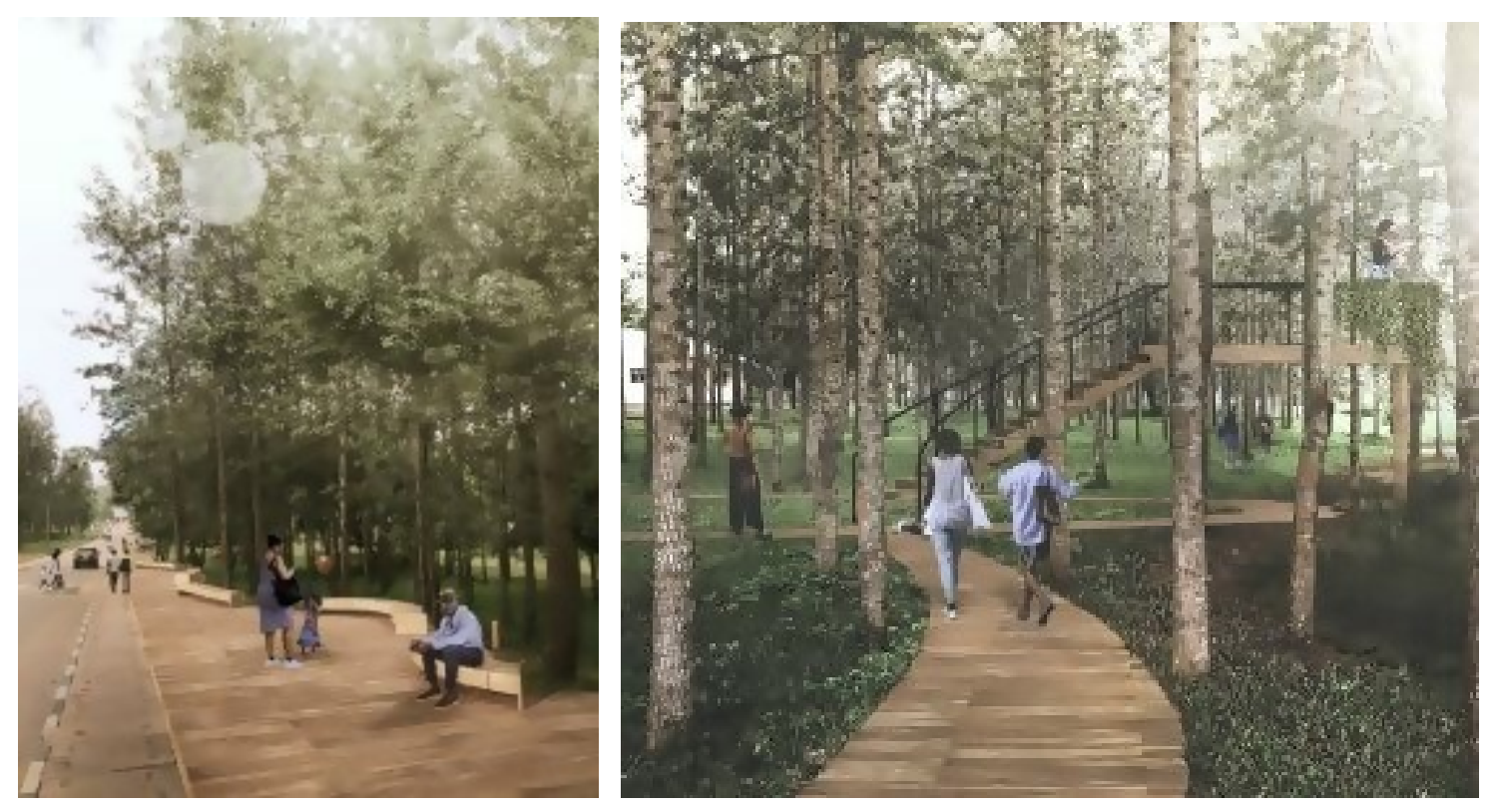

Figures 3 and 4. Final design of green and public space in Nyagatare, 2019 (Source: Ilija Gubic).

The Masterplan revision of Nyagatare has benefited from a valuable contribution from the Green Climate Fund (GCF) established at United Nations Framework Convention on Climate Change (UNFCCC) Conference of Parties for accelerating access to finance for low emission and resilient development. The GCF objective in Nyagatare enables planning for urban green growth through participatory and well-designed resilient and low emission development strategies as part of the urban development plan guiding 
both public and private investment. Due to the need to green the spatial development guidance frameworks in Rwandan cities, GGGI, which is the delivery partner of REMA in implementing GCF projects, has been invited to contribute to the revision of the master plan for all six secondary cities. This shows that the Rwandan government acknowledges the need for green urban development, but also exposes the reliance Rwanda currently has on external funding for these innovations (Global Green Growth Institute, 2018c).

The Ministry of Infrastructure, Rwanda Housing Authority and the Global Green Growth Institute in partnership with the Rwanda Women's Network undertook citywide public open space survey in Nyagatare (and other secondary cities in Rwanda) to better understand the needs of citizens for public open spaces as well as what facilities and utilities these spaces should include (Rwanda Housing Authority \& Global Green Growth Institute, 2019). Most of the surveys were conducted close to the market, school, and border crossing with the Democratic Republic of Congo in Rubavu, all of which are known for their vibrant social scene. The distribution of responses across the city is largely uniform.

The surveys were conducted between August and November 2018. The survey was accompanied by a short training session by Global Green Growth Institute staff to surveyors with background information about the project and the types of questions that surveyors might receive. All respondents were asked if they consented to the survey before being asked the first question. The face-to-face surveys were designed to cover more than one theme and included 20 multiple choice and open-ended questions (Global Green Growth Institute, 2018b). Following these processes, the city of Nyagatare hosted a two-day public space participatory design workshop organised by the Ministry of Infrastructure, the Rwanda Housing Authority, and Global Green Growth Institute (Global Green Growth Institute, 2019d). Local authorities assisted with site identification by analysis of land ownership and masterplan and defined the boundaries of the public space: the selected areas belong to the central government and are surrounded by public buildings and commercial areas that would benefit from wellmaintained public space. These surveys followed stakeholder consultations facilitated by Global Green Growth Institute in preparations for the Huye, Nyagatare, and Rubavu DDSs 2018-2024, where public spaces were identified as one of the priorities to support sustainable urbanisation. The initial survey results indicated that Huye, Nyagatare, and Rubavu residents were in favour of safe, inclusive, and accessible green and public spaces and would prefer spaces with child-friendly playground.

The main climate change impacts in Rwanda are drought and floods. In drought-prone areas similar to Nyagatare, studies show that despite the fact that properties close to well-maintained green public open spaces are valued 10\% higher, in times of drought irrigation of green public space is subject to restrictions (Fam et al., 2008). In Nyagatare, the area assigned for the city's public space is part of the water management system, containing drains. These facilities can integrate multi-layered approaches to urban systems, combining public space design with urban water management. For example, through the creation of retention ponds, the water runoff from slopes is reduced while the presence of water can be used for design purposes and for irrigation. In the context of Rwanda, where rapid urbanisation is resulting in densification, thus reducing the residential garden size, there should be public gardens and open areas for both water management and public space. A study comparing 'business as usual' with an innovative 
irrigation system showed that the use of locally sourced, untreated water was more efficient for irrigating community gardens, public parks, and recreational landscaping if the neighbourhood was designed in a water-efficient way (Dhakal, Syme, Andre, \& Sabato, 2015). In implementing Rwanda's urban agenda to enable green public spaces to add economic value to the neighbourhood, multi-institutional cooperation is required as well as water-efficient neighbourhood design.

The public space design workshop in Nyagatare mobilised citizens from different backgrounds to engage in the participatory design process, with each group listing the main elements that should be incorporated in the public space to ensure they do not affect the functioning of the existing ecosystems. The participatory design included a 'live' advisory session where all participants reached a consensus on where the public space design elements should be located within the site (Global Green Growth Institute, 2019d).

In Nyagatare, although the DDS refers to resilience in terms of agricultural production, in an urban context, the masterplan revision process defines resilience in terms of actions at the household level (such as rainwater harvesting systems), in construction and building (through the promotion of green building codes), water management systems and public open spaces that can be used for improving climate resilience. For example, in Nyagatare, public open space, coupled with agroforestry and water management, can support water retention for longer periods and its use for community gardens and public space maintenance, important in particular during the prolonged drought periods (Dhakal et al., 2015). The allocated site for public space is part of the proposed city-wide resilience infrastructure that could include a series of open spaces (Parker \& Simpson, 20I8), water and infrastructure works, and a green network linking the peri-urban ecosystems with urban green areas. While supporting increased resilience, the public spaces will also support the absorption of greenhouse gas emissions (Andriono, Hanafi, \& Yanuwiadi, 20I3) and so reduce the heat island effect, improving microclimate and regulating temperatures in particular in the dry season. At the same time, this approach promotes gender equality and socio-economic inclusion through safe, accessible public spaces for all.

\section{Conclusion}

The Rwandan government works on implementing initiatives to tackle environmentrelated public health risks. With increasing urbanization, the reduction of GHG emissions remains essential. Government entities are working to implement electric mobility, Bus Rapid Transit, restoration and design of wetlands as green public open spaces, and the revision of the masterplan for Kigali and six secondary cities to respond to climate change realities. Masterplanning provides entry into urban spatial and transport planning, development, and landscape design, including city extensions and renewal across neighbourhood, city wide, metropolitan and district scales. The masterplan revision also creates momentum for improving health. A healthy urban planning practice requires: codes and regulations in the construction sector, which Rwanda is proactive in developing; planning standards which are defined by the masterplan revision as a guiding framework for Kigali and secondary cities; periodic public open space activities organized by communities and city leaders; and public space participatory design which the Global Green Growth Institute promotes. Design 
guidance and regulatory frameworks are yet to be incorporated in the urban landscape of Kigali and secondary cities, while the efforts of different agencies to protect and enhance public health are not being well documented in relation to urban planning.

\section{References}

Andriono, F., Hanafi, I., \& Yanuwiadi, B. (20I3). Green open space scenarios in reducing $\mathrm{CO} 2$ emissions in Malang City, Indonesia: A dynamic system approach. IOSR Journal of Engineering, 3(6), Pp. I-I3.

Barton, H., Grant, M., Mitcham, C. and Tsourou, C. (2009). Healthy urban planning in European cities. Health Promotion International, 24 (Suppl I). i9l-i99.

Cicea, C., \& Pirlogea, C. (20II). Green spaces and public health in urban areas. Theoretical and Empirical Researches in Urban Management, 6(I), pp. 83-92.

Dhakal, R. S., Syme, G., Andre, E., \& Sabato, C. (20I5). Sustainable water management for urban agriculture, gardens and public open space irrigation: A case study in Perth. Agricultural Sciences, 6, pp. 676-685.

Fam, D., Mosley, E., Lopes, A., Mathieson, L., Morison, J., \& Connellan, G. (2008). Irrigation of urban green spaces: A review of the environmental, social and eco- nomic benefits. Cooperative Research for Irrigation Futures Technical Report (Report 04/08). Sydney: University of Western Sydney.

Florindo, A., Vizeu-Barrozo, L., Cabral-Miranda, W., \& Quieroti-Rodriques, E. (20I7). Public open spaces and leisure-time walking in Brazilian adults. International Journal of Environmental Research and Public Health, I4(6), p. 553.

Global Green Growth Institute. (2018a). GGGl leads “Urban Walk” in Nyagatare. Global Green Growth Institute. Available at http://gggi.org/gggi-leads-urban-walk-in-nyagatare

Global Green Growth Institute. (2018b). Citywide surveys on green and public spaces conducted in Huye, Nyagatare and Rubavu. Global Green Growth Institute. Available at http://gggi.org/significance-of-green-public-space-in-cities-to-human-and-environmentalhealth.

Global Green Growth Institute. (2018c). Green Climate Fund (GCF) Preparatory Awareness Workshop to Support Implementation of the Green City Development Projects in Nyagatare. Global Green Growth Institute. Available at https://gggi.org/green-climate-fund-gcf-preparatoryawareness-workshop-to-support-the-implementation-of-the-green-city-developmentprojects-in-nyagatare/.

Global Green Growth Institute. (2019a). Advocating for Green Cities and Green Buildings during the Urban Walk in Kigali. Global Green Growth Institute. Available at https://gggi.org/advocatingfor-green-cities-and-green-buildings-during-the-urban-walk-in-kigali/.

Global Green Growth Institute. (20/9b). GGGI hosts UN-Habitat's Executive Director at the Inclusive Cities Talk in Kigali, Rwanda. Global Green Growth Institute. Available at https://gggi.org/gggi-hosts-un-habitats-executive-director-at-the-inclusive-cities-talk-in-kigalirwanda/.

Global Green Growth Institute. (2019c). Ministry of Infrastructure and GGGI invite key stakeholders to discuss public space agenda in Rwanda. Global Green Growth Institute. Available at https://gggi.org/ministry-of-infrastructure-and-gggi-invite-key-stakeholders-to-discuss-publicspace-agenda-in-rwanda/. 
Global Green Growth Institute. (2019d). Citizens Participate in the Design Process for Green and Public Space in Nyagatare. Global Green Growth Institute. Available at https://gggi.org/citizens-participate-in-the-design-process-for-green-and-public-space-innyagatare/.

Global Green Growth Institute. (2019e). Rwanda GCF NDA and GGGI are Monitoring the Secondary Cities Master Plan Revision Process to Ensure Low Emission and Resilient Strategies and Incorporated in the Green City Development Plans. Global Green Growth Institute. Available at https://gggi.org/rwanda-gcf-nda-and-gggi-are-monitoring-the-secondary-cities-master-planrevision-process-to-ensure-low-emission-and-resilient-strategies-are-incorporated-in-thegreen-city-development-plans/.

Government of Rwanda. (20I I). Green growth and climate resilience: National strategy for climate change and low carbon development. Kigali: Government of Rwanda.

Grant, M. (2015). European Healthy City Network Phase V: Patterns emerging for Healthy Urban Planning. Health Promotion International, 30, Suppl I, pp. i54-i70. Available at doi: I0.1093/heapro/dav033.

Gubic, I., Baloi, O. (2019). Implementing the New Urban Agenda in Rwanda: Nation-Wide Public Space Initiatives. Urban Planning, Vol. 4. Issue 4, pp. 223-236.

Habitat III Secretariat. (2016). A conference of 30,000 voices. Quito: Habitat III Secretariat. Available at http://habitat3.org/documents-and-archive/final-reports/30000-voices-report.

Habitat III Secretariat. (20I7). Habitat III issue papers. Quito: Habitat III Secretariat. Available at http://habitat3.org/wp-content/uploads/Habitat-III-Issue-Papers-report.pdf.

Hoffimann, E., Barros, H., \& Ribeiro, A. (2017). Socioeconomic inequalities in green space quality and accessibility: Evidence from a Southern European city. International Journal of Environmental Research and Public Health, 14, p. 916.

International Association for Medical Assistance to Travelers (2020). Rwanda general health risks: air pollution. Ontario: IAMAT. Available at https://www.iamat.org/country/rwanda/risk/airpollution\#

Kalisa, E., Nagato, E., et al. (2017). Spatial Temporal Variability of PM2.5 in Urban Areas in Rwanda. Kanazawa International Symposium. Noto Peninsula: Institute of Nature and Environmental Technology, p. I.

Lochhead, H. (2017). Resilience by design: Can innovative processes deliver more? Paper presented at the International High-Performance Built Environment Conference, at the Faculty of Built Environment, University of New South Wales, Australia.

London Healthy Urban Development Unit. (20I4). Healthy Urban Planning Checklist. London: London Healthy Urban Development Unit. Available at https://www.healthyurbandevelopment.nhs.uk/wp-content/uploads/20I4/04/Healthy-UrbanPlanning-Checklist-March-2014.pdf.

Ministry of Infrastructure. (20I5a). Rwanda building code. Official Gazette, 20. Available at https:// bpmis.gov.rw/asset_uplds/files/Rwanda\%20Building \%20Code\%20_Urban\%20Planning\%20Code.pdf 
Ilija Gubic, Oana Baloi

Ministry of Infrastructure. (20I5b). National urbanization policy. Kigali: Government of Rwanda.

Ministry of Infrastructure. (20I5c). Urban planning code. Official Gazette, 20. Available at https://housingfinanceafrica.org/app/uploads/Rwanda-Urban-Planning-Code-upc.pdf.

Ministry of Infrastructure, \& Global Green Growth Institute. (2016). National roadmap for green secondary cities development. Kigali: Government of Rwanda.

Ministry of Infrastructure. (2018). Rwanda committed to fast track green and public spaces. Ministry of Infrastructure. Available at

http://www.mininfra.gov.rw/index.php?id=100\&L=0\&tx_news_pi $1 \% 5$ Bnews

$\% 5 \mathrm{D}=|3| \& t x \_n e w s \_p i \mid \% 5 B d a y \% 5 \mathrm{D}=6 \& \mathrm{tx}$ _news

pil\%5Bmonth\%5D=9\&tx_news_pil\%5Byear\%5D=

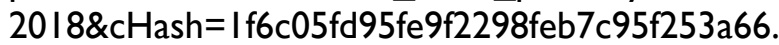

Ministry of Infrastructure. (2019). 3rd National urban forum, Rwanda 2019: Implementing the new urban agenda. Ministry of Infrastructure. Available at http://www.mininfra.gov.rw/index.php?id=2I5.

Ministry of Infrastructure. (2020). 3rd National urban forum report: Implementing the new urban agenda. Ministry of Infrastructure. Available at http://www.mininfra.gov.rw/index.php?id=2 I5.

Ministry of Lands, Environment, Forests, Water and Mines. (2004). National land policy. Kigali: Government of Rwanda.

Ministry of Natural Resources. (2017). National land use planning guidelines. Kigali: Government of Rwanda.

Mogo, E. R., Lerno, A., Abdeta, C., \& Olufemi, O. (2019). Mounting an effective socio-ecological response to non-communicable diseases in Africa's cities. Cities \& Health, Pp. I-6.

NHS London Healthy Urban Development Unit. (2014). Healthy Urban Planning Checklist. London: NHS. Available at https://www.healthyurbandevelopment.nhs.uk/wpcontent/uploads/20 I/04/Healthy-Urban-Planning-Checklist-March-20 I4.pdf.

Nyagatare District. (20I8). Nyagatare District Development Strategy. Nyagatare: Nyagatare District.

Parker, J., \& Simpson, G. (2018). Visitors satisfaction with a public green infrastructure and urban nature space in Perth. Western Australia Land, 7, p. 159.

Peters, K., Elands, B., \& Buijs, A. (2010). Social interactions in urban parks: Stimulating social cohesion? Urban Forestry and Urban Greening, 9(2), pp. 93-100.

Rakhshandehroo, M., Tahir, O. M., Yusof, M. J. M., \& Yunos, M. Y. M. (20I7). The environmental benefits of urban open green spaces: $A$ literature review. Management Research and Practice, 7(4), pp. 60-7I.

Rwanda Parliament (2005). Organic Law N 04/2005 of 08/04/2005. Determining the modalities of protection, conservation, and promotion of the environment in Rwanda. Official Gazette no. 9. I May 2005. Available at https://www.rema.gov.rw/rema_doc/Laws/Environment\%200rganic\%20Law.pdf. 
Rwanda Parliament (20I2). Law N ${ }^{\circ}$ 24/20I2 of 15/06/20/2. Relating to the Planning of Land Use and Development in Rwanda. Official Gazette no. 31 . 30 July 2012. Available at http://extwprlegs I.fao.org/docs/pdf/rwal I 4652.pdf.

Rwanda Environment Management Authority (2017). Rwanda state of environment and outlook report 2017: Achieving sustainable urbanization. Kigali: Government of Rwanda.

Rwanda Environment Management Authority. (2018). Inventory of Sources of Air Pollution in Rwanda: Determination of Future Trends and Development of a National Air Quality Control Strategy. Kigali: Government of Rwanda.

Rwanda Housing Authority \& Global Green Growth Institute. (2019). Mapping of Public Spaces to Inform Master Plan Review for Secondary Cities in Rwanda. Seoul: Global Green Growth Institute. Available at https://gggi.org/site/assets/uploads/2019/09/FINAL-Mapping-of-PublicSpaces_Secondary-cities-in-Rwanda_2309.pdf.

Silva, M., \& Costa, J. P. (2018). Urban floods and climate change adaptation: The potential of public space design when accommodating natural processes. Water, 10(2). Available at https://doi.org/I0.3390/w10020I80.

UN General Assembly. (2016). Outcome document of the Habitat III thematic meeting on public spaces: Barcelona declaration. Barcelona: UN General Assembly. Available at http://habitat3.org/wp-content/uploads/Barcelona-Declaration.pdf.

United Nations. (2016). New urban agenda. New York, NY: United Nations. Available at http://habitat3.org/wp-content/uploads/NUA-English.pdf.

Zivanovic Milic, T., \& Trkulja, S. (2017). Serbia and the Danube area in the light of the new urban agenda. Spatium, 38, pp. 5I-58.

UN General Assembly. (2017). Work of the statistical commission pertaining to the 2030 agenda for sustainable development. New York, NY: UN General Assembly. Available at https://undocs.org/A/RES/7I/3I3.

University of Rwanda. (2018). Rwanda: National Urban Policies and City Profiles for Kigali and Huye. Kigali: GCRF Centre for Sustainable, Healthy and Learning Cities and Neighborhoods (SHLC).

World Bank. (20I6). Rwanda Economic Geography and Urbanization Study; Note 2: Internal Migration. Washington, DC: World Bank.

World Bank. (2017). Reshaping Urbanization in Rwanda: Economic and Spatial Trends and Proposals. Note 4: Profiling Secondary Cities in Rwanda - Dynamics and Opportunities. Washington, DC: World Bank. 